\title{
Darja Hribar
}

University of Maribor

Faculty of Education, Department of English and American Studies

\section{An Examination of Lexical Choices in Slovene Translations of British and American Drama}

\section{Summary}

The article examines lexical choices preferred by a noted Slovene translator of dramatic texts. It is based on the assumption that in spite of the fact that lexical choices offer much greater freedom in translation than, for instance, grammatical choices, they are subject to a number of intratextual and extratextual factors defining the genre, the kind of translation, and specific features of individual plays.

Although examples are taken from only one set of translations of Tennessee Wiliams's A Streetcar Named Desire, they also refer to other working and published versions of drama translations into Slovene, including Albee's Who's Afraid of Virginia Woolf?, Miller's Death of a Salesman, Pinter's plays, and Shaw's Pygmalion. The shifts considered in the article relate to register, i.e. factors of language variation affecting lexical choices related to the field, mode, and tenor of discourse.

Key words: drama translation, shifts, register, Tennessee Williams, A Streetcar Named Desire

\section{Leksikalni izbor v slovenskih prevodih angleške in ameriške drame}

\section{Povzetek}

Članek preučuje izbor leksikalnih enot v prevodih znanega slovenskega prevajalca dramskih besedil. Izhaja iz prepričanja, da čeprav $\mathrm{v}$ prevodu izbira besed prevajalcu nudi veliko več svobode kot, na primer, izbira slovničnih oblik, je tudi prva odvisna od številnih zunaj in znotraj besedilnih dejavkov, ki so odvisni od vrste drame, vrste prevoda in posebnih značilnosti posamezne igre.

Čeprav so primeri v članku vzeti samo iz dveh različic slovenskih prevodov ene ameriške drame, to je Williamsovega Tramvaja poželenja, se nanašajo tudi na nekatere druge slovenske prevode angleške in ameriške drame, kot, na primer, Kdo se boji Virginie Woolf? (Albee), Smrt trgouskega potnika (Miller), Pinterjeve igre, Pygmalion (Shaw), itd. Prevodni premiki, ki jih preučuje se nanašajo na register, to je na funkcijsko zvrsti jezika, ki jo določajo polje, način in ton diskurza.

Ključne besede: dramski prevod, prevodni premiki, register, Tennessee Williams, Tramvaj Poželenje 


\section{An Examination of Lexical Choices in Slovene Translations of British and American Drama}

\section{Introduction}

In Lefevere's words, translations are not just texts written in a different language; they also have to fulfil a function in a different place, a different time, a different society and a different culture (Lefevere 1992, 12). Translation is a mater of constant choice, every moment in the process being a moment of decision. Shifts from the source text are inevitable. Even the most adequacy-oriented translation involves shifts from the source text, dictated by differences between the linguistic and cultural systems of the source and target communities. Besides, translators may decide on shifts for stylistic, ideological or other reasons, such as, for instance, especially in the case of drama, to maintain the flow of the message and to comply with expectations of the target text receptors. What is most important is that their decisions should be motivated by and based on a thorough examination of all relevant facts.

In Slovene circumstances, the assumption that a native speaker is automatically capable of translating everything into his/her own language without specific knowledge is still widely held by the general public. This is not surprising. What is surprising is that some literary translators, considering themselves good connoisseurs of language and culture, feel even more confident in this respect. Many existing translations of dramatic pieces, however, show that specific knowledge is essential for the job and that Slovene translators often succumb to the temptation to choose the first solution that comes to mind without considering its wider literary or social impact.

Though today Slovene literary translators are widely aware that the aesthetic effect of literature resides in the way it is expressed and formed through language, they tend to neglect this intrinsic connection when translating. The lack of a more systematic approach to translation leads to many unmotivated shifts.

The most common shifts in Slovene translation of English dramatic literature are those relating to different levels of meaning of lexical units. Such translations show an absence of the study of the relationship between language activity and the social context in which it takes place (Hatim and Mason 1990, 1997), a lack of constant decisionmaking process as to the function of both texts in their several contexts (Vermeer and Reiss 1984; Nord 1997), and a pronounced emphasis on "semantic" rather than "communicative" translation (Newmark 2003). Above all, Slovene drama translators seem unable to remain consistent with previously introduced translation strategies and norms. This is only partially dependent on the fact, as Uroš Mozetič rightly puts it, that "the Slovene language is not very well dictionarized and that it lacks the recording of the range of its nonstandard varieties", which is especially relevant for drama translation. 
It, to a much greater extent, depends on the fact, that (again in Mozetičs words) the majority of Slovene literary translators are "self-made translators with a good feeling for language" $(1995,123)$ but insufficient specialized knowledge. Slovene drama translators are often playwrights or dramaturges capable of considering special features important for shaping the process of meaning in drama (such as nonverbal communication, visuals and design, music and sound etc.), but not literary translation "scholars" (Lefevere 1992, 92). This is particularly noticeable in their unmotivated mixing of different levels of language variation, especially register. Besides, the examined Slovene translations of plays do not make a distinction between translation of plays intended for publication and those intended for specific production, the distinction usually denoted in terms of retrospectiveness/adequacy versus prospectiveness/acceptability of translation (Toury 1980; Van den Broeck 1986).

\section{Lexical choices and style}

Lexical choices depend to a great extent on the style of writing. As Leech and Short put it, when studying style, we approach texts from the linguist's angle. We do not ask ourselves so much what is being said but why and how something is being said. So when considering style we are not interested in semantic features of a text but in the way a semantic context is communicated to the reader. To be able to establish this, we have to constantly move from linguistic details to the literary centre of a work (Leech and Short 1981, 13). This involves a constant process of interpretation. The process always reflects the interpreter's "own mental and cultural outlook, despite the best of impartial intentions" (Hatim and Mason 1990, 11). The more knowledgeable the interpreter is, the more linguistic, literaryhistorical and cultural features she or he is capable of detecting. What is not detected in the original is usually lost in translation.

Linguists and translatologists divide style into individual and social levels. Individual style is defined as the marked, expressive quality of language, that is, its illocutionary power (Lefevere, 1992), being the result of motivated choices made by text producers. Social styles (Hatim and Mason 1990, 38-9) vary according to the use and/or user. Use-related varieties are known as registers (differing from each other primarily in language form, that is, grammar and lexis); user-related varieties are called dialects, capable of displaying differences at all levels (graphic, lexico-grammatical, and relevant extra-linguistic features), but differing from person to person primarily in the phonic medium. Social styles include register, idiolect and dialects (geographical, temporal, social, and (non-)standard).

Great authors have always also been great artists in the choice and use of words. If the translators want to give credit to the author and to act professionally and respectfully towards their readers/spectators, they should make all possible efforts to establish basic features of the original and to functionally transfer these into another language and culture. This is however not always the case. Let us take some examples. 
For the sake of brevity, this presentation focuses on a consideration of the most typical stylistic shifts in two Slovene translations of Williams's A Streetcar Named Desire, both done by the same translator and available in working and published versions. The findings however also relate to a number of other Slovene translations of dramatic literature (such as, for instance, Albee's Who's Afraid of Virginia Woolf?, Miller's Death of a Salesman, Shaw's Pygmalion and Pinter's plays) and include a wide range of other shifts, too.

\subsection{Register shifts in Zdravko Duša's translation of Tennessee Williams's play $A$ Streetcar Named Desire: the characterization of Blanche and Stanley}

There are four Slovene translations of the play. The first, a working translation, is by Herbert Grün (1952), the second is a TV adaptation, and the remaining two are by Zdravko Duša. Grün's translation of the play is very old, abounding in obsolete and "proper" language, which often sounds strange in its context. The first Duša translation (1999/2000) was originally intended for the first Slovene production of the play (here referred to as D1); the second was published in an anthology of American drama (Kralj 2001), here referred to as D2. There are, however, no essential differences between the two translations concerning register. Though having "polished" certain passages of the text, in general Duša's published translation of the play is essentially the same as the working one. Regarding the intial norm (Toury 1980, 54) and prevailing translation strategy, both translations can be termed retrospective, since textual relations and norms expressed by this have in principle been subjected to the original text. The translator, however, adopted a different strategy relating to register, thus ultimately coming up with a markedly different product. Let us consider an example.

In the original rendering, the protagonists of the play, Stanley and Blanche, show obvious, striking and even shocking differences. In Slovene translation, this distinction is completely blurred.

\subsubsection{Characterization of Stanley}

Stanley is an ordinary, uneducated and rude man, a characterization which is obvious from his acts as well as language. He expresses himself in colloquial or even lower colloquial English, often resorting to abusive language, too. Let us see how the authors' lexical choices are rendered into Slovene and what consequences the shifts have.

\section{Changing slang and non-standard language into standard language}

When translating Stanley's cues, Duša often changes slang and non-standard language into standard language, thus making Stanley sound more polite and educated than he really is. Though proving a good conoisseur of both levels of language, Duša is not consistent in translation. Let us take some examples. 
(i) Stanley after a few first casual sentences with Blanche inquires (my emphases as in the subsequent text):

STANLEY: You (non-standard for "you're) going to shack up (slang for "live, dwell) here? (Williams 1989, 1829)

STANLEY: Računaš ostat (non-standard)? (D1, 20)

Se boš tu naselila (standard)? (D2, 86)

(ii) Stella tries to prevent Stanley from being rude to Blanche, but Stanley is determined to stay and to have a talk with Blanche about the loss of Belle Reve:

STANLEY: You're damn tootin' (slang obs for you won't stop me). I'm going to stay here. (Williams 1989, 1832)

STANLEY: Seveda (standard) bom ostal, sigurna bodi. (D1, 26)

Normalno (standard), da bom ostal. (D2, 90)

(iii) Stanley and Blanche have a conversation about women. Stanley is commenting on his relationship with a glamorous self-centred lady, who constantly refers to how glamorous she used to be. His response was "So what?" When Blanche asks him what the lady said then, Stanley answers:

STANLEY: She didn't say nothing (non-standard). That shut her up like a clam (nonstandard). (Williams 1989, 1833)

STANLEY: Nič ni rekla (standard). Bila je tiho ko rit (vulgar). (D1, 28; D2, 91)

No change of register

(i) Stanley wanting Blanche to stop pretending says:

STANLEY (booming): Now let's cut the re-bop (slang)! (Williams 1989, 1833)

STANLEY (zagrmi): Zdaj pa nehajva nakladat (slang)! (D1, 28; D2, 91)

(ii) Stanley to Mitch during the poker game:

STANLEY: /.../ Get y'r ass of the table (vulgar), Mitch. /.../ (Williams 1989, 1836)

STANLEY: /.../ Rit dol z mize (vulgar), Mitch! /.../ (D1, 33; D2, 95)

(iii) Stanley to his poker friends who want to restrain him from doing Stella some more harm:

STANLEY: Let's the rut go of me, you sons of bitches (vulgar)! (Williams 1989, 1841)

STANLEY: Kurbe pizdunske, pustite me, da se zgonim (vulgar)! (D1,45; D2, 103)

The above, and many other, examples show that in Stanley's case Duša mostly retains the language level of the original, especially when it comes to vulgar and offensive expressions. He, however, tends to embellish Stanley's speech. 


\subsubsection{Characterization of Blanche}

In the original Blanche is an educated lady, expressing herself in either a highly motivated personal use of language (personal style) or standard English. Her language is in sharp contrast with the lower colloquial or colloquial language (sociolect) used by Stanley and his poker friends. Blanche is well read, highly intelligent and cultured. She is also an extremely passionate and unrealistic person, expressing herself with rich, colourful and imaginative language. Her language betrays the fact that she actually lives in the world of poetry and dreams of an idealized past. She is particularly versed in the strange, exotic and weird, all features characteristic of Poe's poetry, which she keeps quoting throughout the play. Her use of alliteration, for instance, serves to point out her poetic, emotional and vulnerable nature.

In addition, Blanche is capable of creating ironic and parodistic effects. In fact irony and parody are her strongest weapons. No other character in the play is capable of creating such a discrepancy between the polite, formal (even hyperformal), imaginative language and the situation in which it is used.

\section{Preserving alliteration but changing imaginative into colloquial language}

(i) Blanche notices that Stella has gained some weight:

BLANCHE: / .../ But you, you've put on some weight, yes, you're just as plump as a little partridge (alliteration)! And it's so becoming (standard) to you! (Williams 1989, 1825)

BLANCHE: /.../ Ampak ti - ti si se majčkeno zredila, ja, pravi polhek (alliteration) si. Nimaš pojma, kako ti paše (lower colloquial)! (D1,13; D2, 80) ${ }^{1}$

\section{Changing alliterative and imaginative into colloquial language}

(i) Reproaching Stella for blaming her for the loss of the house and all the other family possessions, Blanche cries out:

BLANCHE: / I../ Sit there and stare (alliteration, standard) at me, thinking I let the place go! (Williams 1989, 1826)

BLANCHE: /.../ Sedi tam in me glej zabodeno (no alliteration,colloquial), češ: domačijo je zapravila! /.../ (D1, 17; D2, 84) ${ }^{2}$

\section{Lessening ironic and parodistic overtones}

(i) Realizing that Stanley is convinced that she has cheated her sister and him and that she is hiding some possessions from them, Blanche ironically remarks:

BLANCHE: What in the name of heaven are you thinking of? What's in the back of that little boy's mind of yours (insulting)? That I am absconding

2 Alliteration and standard Slovene are possible here: sedeti, strmeti (for the English "sit" and "stare"). 
(formal) with something, attempting some kind of treachery on my sister? /.../ (Williams 1989, 1834)

BLANCHE: Pa kaj za božjo voljo misliš! Kaj se ti mota po otročjih možgančkih (insulting)? Da te fintiram (slang), ker hočem ne vem kako ogoljufat svojo sestro? /.../ (D1, 30; D2, 92)

(ii) Stanley notices some papers in Blanche's trunk, wanting to see them all to verify if Blanche is telling him the truth. Blanche reacts:

BLANCHE: Ipicking up a large envelope containing more papers/ There are thousands of papers, stretching back over hundred of years, affecting Belle Reve as, piece by piece, our improvident grandfathers and father and uncles and brothers exchanged the land for their epic fornications (formal) - to put it plainly! /.../. IShe pours the contents of the envelope on the table./ Here all of them are, all papers! I hereby endow you with them! (byperformal) Take them, peruse them (hyperformal) - commit them to memory, even! I think it's wonderfully fitting that Belle Reve should finally be this bunch of old papers in your big, capable hands! /.../ (Williams 1989, 1834)

BLANCHE: vzame veliko kuverto, v kateri so prav tako papirji: Na tisoče papirjev je, za sto let in več nazaj, v zadevi Belle Reve, ko so najini lahkomiselni dedje in oče in strici in bratje posestvo košček za koščkom menjali za svoje junaško vlačuganje (D1 pejor) /kurbirske podvige (D2 low coll) - po domače povedano! / . . I (Izsuje vsebino kuverte na mizo.) Tu imaš vse papirje, vse! Izvoli jih prevzeti! (D1) /Izvoli, tu ti jih izročam (standard) (D2)/ Vzemi jih, preuči jih (standard) - nauči se jih na pamet, magari! (coll) Zdi se mi res kot nalašč (D1)/mislim, da je več kot primerno(D2)/, da Belle Reve nazadnje pristane (D1)/konča (D2)/ kot kupček starih papirjev v tvojih velikih, sposobnih rokah! /.../ (D1, 31; D2, 93-4)

There are additional colloquialism of the above types in the translation, all of which sound rather strange in the general context of the situation and tenor of discourse.

The most common shifts on the linguistic level of the play fall into the category of stylistic shifts with respect to the register element (tenor of discourse). Register provides information on the social distance between participants in the language situation (Leuven-Zwart, 1989). The result of Dušàs frequent use of colloquialism instead of Blanche's educated formal and/or hyperformal tenor, on the one hand, and her rich, imaginative and poetic language, on the other, lessens the social distance between her and Stanley and considerably changes Blanche's characterization in translation. In Slovene translation, Blanche often sounds as rude and uneducated as Stanley, which was certainly not Williams's original intention. What is more the translator's willingness to degrade her language reveals a pronounced traditional male perception of the promiscuous woman as whore. 


\section{Conclusion}

A minute comparison of specific areas of language choice of a number of Slovene translations of plays often reveals the absence of a more systematic approach to the study of individual levels of language and a pronounced emphasis on the use of one register in different literary and pragmatic contexts. This complies with the assumption of Toury who finds that "translator's behaviour cannot be expected to be fully systematic. Not only can his/her decision-making be differently motivated in different prolem areas, but it can also be unevenly distributed throughout an assignment within a single probem area" (Toury 1995, 67). Toury's assumption certainly proves true in the above examples. In our case it also points to an ideologically and stylistically tinged approach to translation, one which dismisses a more "scholarly" approach as unnecessary and not worthy of a true artist. The latter, however, often results in the lessening of that same true artistic value of the original it proclaims to preserve in translation.

\section{Bibliography}

Broeck, van den R. 1986. Translating for the Theatre. Linguistica Antverpensia 1, no. 2: 96-100.

Duša, Z., trans. 1999/2000. Tramvaj Poželenje. Working translation. SNG Ljubljana.

- - -., trans. 2001. Tramvaj Poželenje. In Kralj, ed., 69-158.

Grün, H., trans 1952. Tramvaj Hrepenenje. Working translation. PG Kranj.

Hatim, B., and I. Mason. 1997. The Translator as Communicator. London: Routledge.

- - - 1990. Discourse and the Translator. London and New York: Longman.

Kralj, L., ed. 2001. Ameriška drama 20. stoletja. Ljubljana: Karantanija.

Leech, G.N., and M.H. Short. 1981. Style in Fiction. A Linguistic Introduction to English Fictional Prose. London and New York: Longman.

Lefevere, A. 1992. Translating Literature: Practice and Theory in a Comparative Literature Context. New York: The Modern Language Association of America.

Leuven-Zwart, van K. 1989. Translation and Original: Similarities and Dissimilarities I. Target 1, no. 2: 151-81.

Mozetič, U. 1995. The Impact of Translation Deviation upon the Reception of Eugene O'Neill's Plays in Slovenia. In American Literature for Non-American Readers: Cross-cultural Perspectives on American Literature, ed. M. Grosman, 123-38. Frankfurt am Main: Peter Lang.

Newmark, P. 2003. A Textbook of Translation. London: Longman.

Nord, C. 1997. Translating as a Purposeful Activity: Functionalist Approaches Explained. Manchester: St. Jerome.

Reiss, K., and H.J. Vermeer. 1984. Grundlegung einer allgemeinen Translationstheorie. Tubingen: Max Niermeyer.

Toury, G. 1980. In Search of a Theory of Translation. Tel Aviv: The Porter Institute for Poetics and Semiotics.

- - -. 1992. Descriptive Translation Studies and Beyond. Amsterdam/Philadelphia: John

Benjamins Publishing Company.

Williams, T. 1989. A Streetcar Named Desire. In Norton Anthology of American Literature II, ed. N. Baym et al., 1818-78. New York, London: Norton and Co. 